\title{
KAROLINA DĘBSKA
}

iD https://orcid.org/0000-0003-2789-1571

Uniwersytet Warszawski

k.debska@uw.edu.pl

\section{O NIEWIDOCZNOŚCI TŁUMACZA RAZ JESZCZE. NA PRZYKŁADZIE TŁUMACZEK W POLSCE 1697-1763}

\section{Abstract}

Translator's Invisibility Revisited: The Case of Women Translators in Poland in 1697-1763

This paper analyses the impact of social trajectories of translators on their translatorial behaviour on the example of women translators in Poland in the years 1697-1763. My aim is to find out who they were as well as sketch the circumstances in which they had to live and work and analyse how it impacted their translatorial behaviour. It is assumed that translatorial habitus makes translators invisible and submissive. In the article, I argue the contrary: in the case of early women translators in Poland, taking up this profession required high status and lead to increased visibility.

Keywords: habitus, translatorial behaviour, social trajectory, capital, women translators, sociology of translation, history of translation, $18^{\text {th }}$-century women translators, translator's invisibility

Słowa kluczowe: habitus, zachowanie translatorskie, trajektoria społeczna, kapitał, tłumaczki, socjologia tłumaczenia, historia tłumaczenia, thumaczki osiemnastowieczne, niewidoczność tłumacza

Jean Delisle i Judith Woodsworth piszą w swoim wstępie do Translators Through History: „Historia przekładu pomaga tłumaczom, tym dyskretnym pracownikom, wyjść z cienia" (2012: XX). Dzięki opisowi ich trajektorii 
społecznych, historia tłumaczenia powinna też pomóc określić ich habitus i wyjaśnić ich zachowania translatorskie. Celem tego artykułu jest więc spojrzenie na tłumaczki okresu saskiego, czyli czasów, kiedy Polki po raz pierwszy sięgnęły po pióro (Maciejewska 2008: 228, 231), opisanie ich trajektorii społecznych i habitusu oraz analiza ich zachowań translatorskich ${ }^{1}$.

Daniel Simeoni (1998) pisze, że habitus tłumacza zakłada niewidoczność, niższość i uległość 2 . W niniejszym artykule chciałabym wykazać, że nie są to cechy, którymi charakteryzowały się polskie tłumaczki z pierwszej połowy XVIII wieku. Musiały one dysponować różnymi typami kapitałów, żeby zapewnić sobie dostęp do pola kultury, a kiedy już znalazły w nim miejsce, nie były niewidoczne ani uległe; nie leżało to również w ich zamiarach.

Socjologiczne podejście do tłumaczenia zakłada zajęcie się badaniem tłumaczy raczej niż tekstów, pozwala na podkreślenie roli tłumaczy w procesie przekładu (Inghilleri 2005: 126), a także wyjaśnienie, jak ich habitus przyczynia się to tworzenia i reprodukcji praktyk i norm thumaczeniowych (Simeoni 1998: 26; Inghilleri 2005: 135; Wolf 2007: 19). Użyte w niniejszym artykule podstawowe pojęcia socjologii thumaczenia zostały zaczerpnięte z socjologii Pierre'a Bourdieu (1998) oraz z jej zastosowań w przekładoznawstwie zarówno z perspektywy teoretycznej (np. Simeoni 1998; Inghilleri 2005; Gouanvic 2007; Wolf 2007; Vorderobermeier 2014), jak i praktycznej (np. Gouanvic 1995; Meylaerts 2010; Sela-Sheffy 2005; $\mathrm{Xu}, \mathrm{Chu} 2015)$. W ujęciu socjotranslatorycznym tłumaczenie bada się jako działanie społeczne, wynik konfrontacji habitusu tłumacza i jego pozycji w polu (Gouanvic 1999: 16). Zakłada się, że jest ono kształtowane zarówno przez obiektywną strukturę zewnętrzną, między innymi przez interesy narodowe, religię czy ekonomię, jak i przez tłumacza, który uwewnętrznił tę strukturę w postaci habitusu (Wolf 2007: 1).

${ }_{1}$ Przedmiot ten nie był dotychczas w Polsce tematem wielu badań - brak kompletnej historii polskich tłumaczek osiemnastowiecznych, chociaż istnieją opisy poszczególnych przypadków, jednak przede wszystkim tłumaczek stanisławowskich (np. Łukaszewicz 2010). Większość europejskich opracowań na temat tłumaczek tego stulecia (w Wielkiej Brytanii: Agorni 2005; Brown 2005; w Niemczech: Wolf 2005; we Francji: Pieretti 2002; Garnier 2002; i Whitfield 2002) dotyczy oświecenia, co nie dziwi, jednak nie pozwala na bezpośrednie porównania z sytuacją w Polsce przed rokiem 1763. Mimo to tam, gdzie to możliwe, będę próbowała zestawiać swoje wnioski z konkluzjami zachodnioeuropejskich autorek.

${ }^{2}$ Marie-Pascale Pieretti nazywa bycie tłumaczem ,niepełnym autorstwem” [reduced authorship] (2002: 474). 
Żeby zbadać, jakie czynniki oddziaływały na kobiece tłumaczenie w Polsce czasów saskich, podobnie jak Bourdieu w analizie francuskiego pola literackiego (1998) rozpocznę więc od opisania wpływu innych pól na pole literackie w ogóle oraz na tę jego część, którą zajmowały przekłady, a także naszkicuję sytuację w samym polu. Następnie przeanalizuję biografie tych kobiet, aby sprawdzić, czy możliwe jest ustalenie habitusu grupowego, a w końcu opisać, jak ich doświadczenia kształtowały ich zachowania translatorskie. Mam nadzieję ustalić, które elementy ich habitusu czyniły je niewidocznymi, a które wręcz przeciwnie, przyczyniały się do ich widoczności.

Poszukiwania bibliograficzne pozwoliły na znalezienie dziewięciu tłumaczek żyjących w tych czasach: Marii Beaty Zawiszanki, tłumaczki Artamène ou le Grand Cyrus Madeleine de Scudéry (1719); Aleksandry Lanckorońskiej, która przełożyła Jeana Crasseta Rozmowy między mistrzem a uczniem o sakramencie ciała pańskiego (1735); Barbary Radziwiłłowej, autorki thumaczenia Dianei Francesca Loredana (przed 1746 rokiem); Franciszki Urszuli Radziwiłłowej, która spolszczyła trzy sztuki Moliera oraz tekst religijny Thomasa Sailly'ego (1748); Marii Potockiej, tłumaczki dwóch sztuk Moliera (przed 1749 rokiem); Antoniny Niemiryczowej, która przetłumaczyła Feniksa rzadkiego na świecie Jeana de Préchaca (1750) i być może anonimowe Rady dane przyjaciółce przez P.P. (1755); Elżbiety Szczuki, która w 1751 roku wydała przekład Słodkiej $i$ świętej śmierci Jeana Crasseta; Teofili Moszyńskiej, autorki polskiej wersji Rad madrości Michela Boutaulda (1754); oraz Elżbiety Wielhorskiej, która przełożyła wiele francuskich utworów teatralnych, z czego znany z tytułu jest Patelin patron Davida Augustina de Brueysa.

Gromadzenie danych biograficznych dotyczących tłumaczek czasów saskich jest często trudne. Pierwszymi źródłami były: Bibliografia staropolska Estreichera, Polski słownik biograficzny (PSB), Wielka genealogia Minakowskiego i Herbarz Polski, w których poszukiwałam informacji o tłumaczkach i członkach ich rodzin w celu ustalenia ich tożsamości; następnie szukałam źródeł dotyczących poszczególnych tłumaczek w katalogach bibliotecznych Biblioteki Narodowej i NuKAT, a także w źródłach internetowych i publikacjach dotyczących historii, literatury i kultury tego okresu (użyte źródła są wymienione na końcu każdej notki biograficznej). O pięciu z tych kobiet zachowało się więcej danych, które zostaną przedstawione poniżej i posłużą za podstawę analizy. W czterech pozostałych przypadkach znalezione informacje są szczupłe i często frustrująco schematyczne (por. Zawiszewska 2010: 50-51, która opisuje problemy, jakie napotykają 
w Polsce biografowie kobiet wszystkich epok), nie zawsze można więc wysnuć z nich pewne wnioski, bo udało się ustalić jedynie podstawowe fakty, pozwalające na określenie pochodzenia społecznego tych kobiet i wyboru przetłumaczonych dzieł (na stronach tytułowych swoich przekładów często są określane wyłącznie jako czyjeś żony, siostry czy córki lub też informacje o nich pochodzą z krótkich wzmianek w przypadkowych źródłach; notki ich dotyczące znajdują się w Załączniku, a w samym artykule informacje o nich są przytaczane jedynie sporadycznie).

\section{Okoliczności historyczne, polityczne i społeczne}

Czasy saskie w Polsce są powszechnie uznawane za kulminację upadku kulturalnego Polski, o którego politycznych przyczynach tak pisze Czesław Hernas: „W 1648 roku rozpoczął się regres państwa, które u schyłku baroku, w pierwszej połowie XVIII w., zmniejszyło się o więcej niż 1 \%, a stan zaludnienia, skutkiem utraty ziem, zmniejszonej populacji, zniszczeń wojennych, zmalał o ok. 40\%" (Hernas 2002: 11).

Mieczysław Klimowicz dodaje:

Kiedy na zachodzie i wschodzie Europy powstają nowoczesne monarchie absolutne, które budowały swą siłę na podstawie sojuszu z burżuazją i średnią szlachtą przeciw decentralizacyjnym tendencjom magnackiej oligarchii, protegowały rozwój handlu i przemysłu (...) - w Rzeczpospolitej szlacheckiej następuje rozkład państwowości, osłabienie pozycji króla oraz wzrost znaczenia magnaterii, pretendującej do roli udzielnych władców swoich olbrzymich latyfundiów, prowadzących własną politykę zagraniczną i wewnętrzną (Klimowicz 2002: 11).

Autorzy niuansują co prawda ten negatywny osąd, zwracając uwagę, że już w latach 30. XVIII wieku widać pewne oznaki poprawy, pierwsze symptomy oświecenia, ale są właściwie zgodni, że niemal do końca epoki saskiej dominujący nurt to anarchia, upadek miast i niewolnictwo chłopów, dominacja agresywnego katolicyzmu, która doprowadziła do nietolerancji religijnej, obskurantyzmu i - co nawet bardziej istotne dla pola kultury cenzury kościelnej (Klimowicz 2002: 11-16; Hernas 2002: 19-20, 423-424).

Właśnie silną i uprzywilejowaną pozycją Kościoła w polu wydawniczym Krzysztof Migoń (1967) tłumaczy głęboki kryzys ówczesnych wydawnictw, w szczególności w pierwszych czterdziestu latach XVIII wieku. 
Autor precyzuje, że dodatkowymi czynnikami były niedostatek czytelników, panująca kultura rękopiśmienna oraz bezpośredni dostęp do książek obcych wśród czytającej elity (1967: 32-34, 53). Miało to niebagatelne znaczenie także dla obszaru przekładowego: wśród publikacji obcych wyraźnie przeważały książki religijne, w szczególności popularne (Migoń 1967: 38-40), a literatura piękna - tłumaczona głównie z łaciny, ale pod koniec okresu również z języka francuskiego oraz (w przypadku tekstów teatralnych) z włoskiego - stanowiła 20\% wszystkich przekładów (Migoń 1967: 43-50). Pisząca o prozatorskich przekładach powieści w XVIII wieku Irena Łossowska naliczyła w czasach saskich jedynie 38 pozycji, najczęściej pochodzących z łaciny, niemieckiego, włoskiego i francuskiego, wyraźnie mniej niż w drugiej części stulecia (2002: 17-18).

Jednocześnie dość paradoksalnie w tym najciemniejszym okresie uaktywniają się na polu intelektualnym kobiety (Maciejewska 2008; Dziechcińska 2005). Maria Bogucka (2004: 130) przypisuje to novum kryzysowi edukacji męskiej w drugiej połowie XVII wieku, który sprawił, że to kobiety zaczęły odgrywać większą rolę w życiu kulturalnym Polski, „w sposób świadomy wyszły poza rolę przypisywaną wówczas ich płci, rolę żony i matki, wkraczając w rejony męskiej dominacji” (Maciejewska 2008: 213). Edukacja kobiet była wtedy na takim samym albo nawet wyższym poziomie niż męska, dziewczynki uczyły się w szkołach zakonnych, prywatnych albo w domu, nieraz z braćmi, pod okiem zawodowych nauczycieli, często cudzoziemskich guwernantek (Bogucka 2004: 131).

Oczywiście nie oznacza to poprawy ogólnej sytuacji kobiet: po pierwsze, mowa wyłącznie o przedstawicielkach arystokracji (Bogucka 2008: 126); po drugie, nawet w tej sferze kobiety nie cieszyły się prawami równymi męskim: nie mogły dziedziczyć na takich samych zasadach (Pietrow-Ennker 1992: 5), nie mogły same uczestniczyć w życiu publicznym, tylko przez męskich opiekunów (Roman 1962: 396-398), w całej Europie nadal toczyła się przecież debata na temat naturalnej niższości kobiet, w XVII wieku wyjątkowo mizoginistyczna, w następnym stuleciu równie nienawistna, chociaż już odrobinę mniej prymitywna (Bogucka 2008: 72-89).

Pokazuje to wyraźnie, że pole literackie nie było autonomiczne, a wydarzenia z szerszego pola polityki i życia społecznego miały przemożny wpływ na jego kształt i bardzo go osłabiały. Cenzura, bieda i sytuacja szkolnictwa sprawiały, że kultura docierała do bardzo niewielkiej grupy ludzi, a wiele tekstów, także przekładów, nigdy nie zostało opublikowanych. Ksenofobia i nietolerancja prowadziły też do tego, że przekłady stały się rzadkością, 
tym bardziej że nieliczni potencjalni czytelnicy mieli bezpośredni dostęp do obcojęzycznych, zwłaszcza francuskich i łacińskich, oryginałów. Paradoksalnie ta sytuacja sprawiła, że w polu utworzyło się wolne miejsce dla nowych aktorów, które zajęły między innymi omawiane tłumaczki.

\section{Biografie i habitus klasowy}

Zaczniemy od krótkich szkiców biograficznych pięciu tłumaczek, których życiorysy są lepiej znane: wśród wielu cennych faktów skupiam się przede wszystkim na tych, które dotyczą ich kapitałów: społecznego, kulturowego, ekonomicznego i symbolicznego, aby zarysować ich habitus i te jego aspekty, które pomogły im zostać tłumaczkami. Podstawowym celem jest analiza stopnia ich niewidoczności, niższości, marginalności i uległości.

Barbara z Zawiszów Radziwiłłowa (1690-ok. 1770) była najstarszą córką Krzysztofa Zawiszy, wojewody mińskiego, i Teresy z Tyszkiewiczów, a także siostrą Beaty Marii z Zawiszów Wołk-Łaniewskiej, również tłumaczki (por. poniżej). W 1710 roku jej mężem został Mikołaj Faustyn Radziwiłł, wojewoda nowogródzki, z którym miała czternaścioro dzieci; wieku dorosłego dożyli czterej synowie i cztery córki.

Mąż podobno nie był człowiekiem zbyt lotnym i to ona podejmowała w ich związku decyzje. W ogóle źródła zgodnie piszą o jej niezwykłej aktywności życiowej: zajmowała się gospodarstwem, buchalterią, przemysłem, handlem; przejęła od męża ciężar zarządzania dobrami, podnoszenia ich wartości i oczyszczania z długów: „Są dowody - niewzruszone, bo cyframi wypisane - że z przyjętej na się roli wywiązała się znakomicie" (Gomulicki 1912: 366). Miała też znaczny wpływ na poczynania polityczne męża, często w jego imieniu negocjowała kwestie publiczne: „Dyplomaci sascy określali ją jako gwałtowną i wyniosłą. Po śmierci męża pozostała aktywna w życiu politycznym Litwy. W r. 1747 ustalała np. z M.K. Radziwiłłem obsadę godności trybunalskich" (Szklarska 1987). Była dobrodziejką zakonu karmelitów i fundatorką cerkwi unickiej i kościoła farnego w Berdyczowie.

Była kobietą wykształconą, a można też mniemać, że przykład ojca i jego zachęty mogły wywrzeć na nią wpływ. Krzysztof bowiem był pisarzem i oratorem - jego mowy wyszły drukiem, w młodości przetłumaczył romans Historia o Agnulfie, a pod koniec życia Boga nieśmiertelnego w śmiertelnym ciele cierpiacego tragiczna historyje Wilhelma Stanihursta. Wspierał też swoje dzieci w ich próbach literackich. 
Analiza tłumaczenia Barbary Radziwiłłowej dokonana przez Jadwigę Miszalską (2005) pokazuje, że znała francuski i włoski, a także dysponowała słownictwem i wiedzą z różnych dziedzin. Gomulicki (1912) wspomina także, że znała prawo i sama uczyła syna, co również wskazuje na gruntowne wykształcenie. Nie była profesjonalną pisarką, jednak należała do rodziny o zainteresowaniach literackich, a w jej ślady poszedł też jej syn, Udalryk (Gomulicki 1912; Kaczyńska 2014; Maciejewska 2013; Miszalska 2003 i 2005; Szklarska 1987).

Maria Beata z Zawiszów Wołk-Łaniewska (1692-?), córka Krzysztofa Zawiszy i Teresy Róży Tyszkiewiczówny, była młodszą siostrą Barbary i w odróżnieniu od siostry wydała swoje tłumaczenie drukiem (choć, jeśli wierzyć wstępnym, anonimowym słowom jej książki, wbrew swojej woli). O ile można założyć, że jej edukacja i wychowanie było podobne jak siostry, to o jej dalszym życiu zachowało się znacznie mniej danych: była żoną Ignacego Wołk-Łaniewskiego, łowczego, damą cesarskiego Orderu Krzyża Gwiaździstego. Pozostała bezdzietna. Nie wiadomo, czym jeszcze się zajmowała. Lektura Pamiętników jej ojca wskazuje, że w jego oczach przyćmiła ją starsza siostra, która poślubiła księcia, chociaż z drugiej strony Zawisza rozdystrybuował tłumaczenie Marii Beaty wśród swoich znajomych i wspierał ją w jej próbach literackich. W pierwszych słowach swojego opus Zawiszanka pisze: „Z rozkazania osoby, która wielką władzę ma nade mną, wzięłam przedsięwzięcie tłumaczyć z francuskiego języka na polski historię książęcia Aryamena" (w: Scudéry 1719), co może wskazywać, że nie tylko miała oparcie wśród bliskich, ale była wręcz przez nich nakłaniana do tłumaczenia $^{3}$ (Bartoszewicz 1862; Dziechcińska 2005; Kaczyńska 2014).

Antonina z Jełowieckich Niemiryczowa (ok. 1700-1780) była córką Józefa Jełowieckiego. Jako dziecko odebrała staranne jak na owe czasy wykształcenie u panien bernardynek we Lwowie, potem w domu razem z bratem Franciszkiem pobierała nauki od korepetytora z Warszawy, który uczył ją francuskiego, włoskiego i niemieckiego, a także literatury. Była muzykalna, komponowała, podobno też malowała. Jak pisze rozentuzjazmowany jej przymiotami Stanisław Jaszowski (1820), była wykształcona, dowcipna i dobra. Bardziej umiarkowany, lecz często kąśliwy Wiktor Gomulicki zaś twierdzi, że „Panna odznaczała się wyjątkowym w owej epoce głodem wiedzy" (Gomulicki 1912: 301), który szczęśliwie mogła zaspokoić

${ }^{3}$ Chyba że uznamy to wyłącznie za przykład retoryki skromności, jednak inne czynniki wskazują, że rzeczywiście cieszyła się wsparciem bliskich. 
u boku męża, Karola Niemirycza, oboźnego polnego litewskiego, który też był znany z oczytania i gromadził bibliotekę.

W godzinach zbywających jej od świętego powołania żony i matki zabawiała się Literaturą, szczęśliwa, iż dostała męża, który sam będąc oczytanym, na naukowe swojej małżonki zatrudnienia chętnym poglądał okiem; co większa, książek rozmaitego dostarczał jej rodzaju (Jaszowski 1820: 320).

Z mężem mieszkała w jego dobrach w Czerniechowie w Owruckiem, po jego śmierci w Złotyjowie pod Równem, we Lwowie, a przez około dwa lata w Warszawie. Miała dwóch synów, Fryderyka i Bonawenturę. Gomulicki pisze z uznaniem o jej zmyśle praktycznym: „,sprawami majątkowymi zajmowała się osobiście, (...) koła i tryby wielkiej machiny sądowniczej były jej z bliska znane, (...) umiała nawet zdobyć się na krytykę jurystów" (Gomulicki 1912: 364). Pisała też własne poezje, zebrane w tomie Krótkie ze świata zebranie koniektur... i wydane we Lwowie w 1743 roku oraz niewydane późniejsze wiersze.

Była współczesną Franciszki Urszuli Radziwiłłowej, z którą prowadziła korespondencję, niektórzy autorzy (np. Rabowicz 1978) piszą nawet o przyjaźni pomimo różnicy klasy i gustu (Gomulicki 1912; Jaszowski 1820; Rabowicz 1978; Roćko 1998).

Franciszka Urszula z Wiśniowieckich Radziwiłłowa (1705-1753), wojewodzina wileńska, hetmanowa Wielkiego Księstwa Litewskiego, była córką Janusza Wiśniowieckiego i Teofili z Leszczyńskich, a jej mężem od 1725 roku był Michał Kazimierz Radziwiłł zwany Rybeńko. Krótko po ślubie osiadła w Nieświeżu i rzadko go opuszczała - była wątła i chorowita, cały czas w ciąży (około 30 razy). Mimo to prowadziła bardzo aktywny tryb życia: zajmowała się bardzo zaniedbanymi dobrami Radziwiłłowskimi, zwłaszcza pod nieobecność męża, który dużo wojażował. Uczyniła z Nieświeża ośrodek kulturalny, powiększyła i uporządkowała zaniedbaną bibliotekę, odnowiła drukarnię, stworzyła teatr, dla którego pisała, a jej sztuki były wystawiane przy okazji uroczystości rodzinnych przez gości i domowników.

Samodzielnie zdobyła bardzo staranne wykształcenie, podobne najnowocześniejszemu wykształceniu, jakie w tych czasach mogli zdobyć mężczyźni:

Ta miłośnica sztuk wyzwolonych szczególne miała do nich upodobanie. W piśmie świętym, w prawach kościelnych i cywilnych była biegłą, miała doskonałą 
wiadomość ustaw sejmowych, do czego jej rzadka pamięć pomagała. W historii powszechnej, w geografii i statystyce obszerne posiadała wiadomości. Niespracowana była w czytaniu książek, świadczy o tym jej własna biblioteka ze dwóch tysięcy najlepszych autorów złożona, których (...) wszystkich przeczytała (Sowiński 1821: 56-57).

Znała francuski, niemiecki i podstawy włoskiego. Zainteresowanie teatrem wyniosła $\mathrm{z}$ domu, a zamiłowanie do pisania - od ojca pisarza i wuja tłumacza, pozostawiła obfitą korespondencję, poezje własne i tłumaczone, trzy traktaty o małżeństwie (w tym dwa - po polsku i po francusku - są być może tłumaczeniami z nieznanych źródeł $)^{4}$, Przestrogi zbawienne ... dla córki, a nawet rysunki (podobno słabe), według których wykonano ryciny w Komediach i tragediach..., ale:

Do podręczników historii literatury (...) trafiła jako twórczyni szesnastu sztuk. Badacze, którzy niejednokrotnie podważali artystyczną wartość Komedyj i tragedyj, doceniali jednak rolę Radziwiłłowej jako pierwszej polskiej dramatopisarki i tłumaczki utworów Moliera (Maciejewska 2013: 53).

Nawet jej oryginalne utwory są oparte na starszych wzorcach: sielankach pasterskich i alegorycznych, dramatach szkolnych, komedii dell'arte, baśniach i powieściach, dziełach hagiograficznych i średniowiecznych misteriach, a Judkowiak stwierdza wręcz, że większość jej dorobku to tłumaczenia lub kompilacje, chociaż ich źródła są w większości nieznane (Judkowiak 2013: 130). Ocena jej pisarstwa jest wśród badaczy raczej negatywna, chociaż w nowszych opracowaniach znaleźć można także próby jej rehabilitacji:

Sądzić wolno, że często negatywna waloryzacja jej dorobku (ganienie niedostosowania do norm obowiązujących w kulturze oficjalnej) wynikała z niezrozumienia przez krytyków próby wypracowania własnego głosu, odmiennego od propozycji męskiej kultury słowa (Judkowiak 2008: 228).

Barbara Judkowiak podkreśla także, że po jej śmierci wydawca Jakub Fryczyński ,poprawiał” i „barokizował” jej utwory, a Iwona Maciejewska dodaje, że ,wydawca jej sztuk uznał za stosowne ocenzurować swoją chlebodawczynię!” (2013: 70). Żeby podkreślić skalę nowatorstwa Radziwiłłowej,

${ }^{4} \mathrm{O}$ ich niepewnym pochodzeniu i możliwych źródłach wspomina Iwona Maciejewska (2013: 308, zwłaszcza przypis 89), Barbara Judkowiak zaś opisuje je jako przeróbki traktatów Eustache'a de Noble'a (2013: 44-45). 
Judkowiak mówi wręcz o jej „kobiecej «rewolcie»” i ,antysystemowości”, „feminizmie” i ,zmianie paradygmatu” (2013: 109, 119, 401; Bogucka 2004; Judkowiak 2008 i 2013; Maciejewska 2013; Sowiński 1821; Widacka 2016; Wierzbicka-Michalska 1987).

Maria z Kątskich Potocka (ok. 1720-1768) była córką Wiktorii Szczuki, podkanclerzanki litewskiej, i Jana Stanisława Kątskiego, również tłumacza i poety. W 1741 roku poślubiła Eustachego Potockiego, starostę tłumackiego, i - jako ostatnia z rodu Szczuków - wniosła mu olbrzymią fortunę i odziedziczony po dziadku księgozbiór. Mieli ośmioro dzieci, z których sześcioro dożyło dorosłości, a liczne połogi były przyczyną chorowitości Marii. Umarła w 1768 roku podczas podróży do Warszawy.

Po śmierci rodziców, już jako nastolatka, Maria sama rozporządzała swoim majątkiem, gromadziła bibliotekę, zwłaszcza francuskojęzyczną. Niewiele wiadomo o jej wykształceniu, oprócz tego, że było - zgodnie z ówczesnym zwyczajem - „francuskie”, oraz że niemały wpływ mógł na nią wywrzeć przykład dziadka i ojca, bo obaj trudnili się pisaniem. Wiadomo, że czytywała przede wszystkim romanse, utwory teatralne, pamiętniki i listy i bardzo żywo interesowała się wystawianymi w Warszawie sztukami (Dziubecki 2013; Kowalik 2001; Oworuszko 2014; Rudnicka 1996).

Omawiane tłumaczki tworzą dość jednorodną grupę: wszystkie urodziły się pod koniec XVII lub w pierwszej połowie XVIII wieku i ukształtowała je kultura czasów saskich, nawet jeśli żyły także w epoce stanisławowskiej (zwraca też uwagę fakt, że poza nielicznymi wyjątkami - Zawiszanka, Lanckorońska - prawie wszystkie tworzyły w połowie wieku, czyli u schyłku epoki saskiej i w czasach, kiedy oświecenie polskie stawiało już pierwsze kroki). Były uznawane za bardzo dobrze wykształcone (jak na swoją epokę) i miały do dyspozycji znaczny kapitał kulturowy: w dwóch przypadkach mowa o szkołach klasztornych, w kilku o korepetytorach i guwernantkach; zamiłowanie do książek to również powtarzający się wątek w ich biografiach. Należy też podkreślić, że - inaczej niż sto lat wcześniej, kiedy to wśród garstki nielicznych w Polsce tłumaczek była i królowa, i mieszczanka (Dębska 2016), w czasach saskich wszystkie tłumaczki pochodziły z magnaterii, obracały się w najwyższych kręgach towarzyskich i miały zarówno kapitał ekonomiczny, jak i symboliczny ${ }^{5}$. Zwykle trudniły się też inną działalnoś-

5 To różni je od ówczesnych tłumaczek zachodnioeuropejskich: w osiemnastowiecznej Anglii tłumaczki coraz częściej pochodziły ze sfer niearystokratycznych, ponieważ wykształcenie docierało też do niższych warstw społecznych (Brown 2005: 111); najbardziej 
cią oprócz tłumaczenia i to dzięki tej pozatłumaczeniowej działalności są zazwyczaj pamiętane, a zgromadzony w innych dziedzinach kapitał mogły wykorzystywać w przekładzie: zarządzały dobrami, uczestniczyły w życiu publicznym, były artystkami i pisarkami, gromadziły biblioteki i dzieła sztuki, organizowały teatry amatorskie, zajmowały się działalnością dobroczynną i tym podobną.

Żadna z nich jednak nie wywarła na swoje społeczeństwo takiego wpływu, jaki zdaniem badaczy zachodnich wywierały tamtejsze tłumaczki ${ }^{6}$. Było to zapewne spowodowane tym, że czasy saskie to w polskiej kulturze pierwsza epoka, kiedy kobiety zaistniały w polu literackim. Rzeczywiście, inaczej niż wcześniejsze tłumaczki, które jawiły się jako samotne wyspy, tłumaczki saskie zadzierzgnęły więzy i stworzyły rodzaj luźnej sieci: Barbara Radziwiłłowa i Beata Maria Wołk-Łaniewska były córkami Krzysztofa Zawiszy, pisarza i tłumacza, który bardzo zachęcał swoje dzieci do pracy literackiej; mąż Antoniny Niemiryczowej też był tłumaczem i naukowcem amatorem; Maria Potocka była córką tłumacza i wnuczką pisarza; Franciszka Urszula Radziwiłłowa - córką pisarza i siostrzenicą tłumacza. Co więcej, po raz pierwszy widzimy, że kobiety te mogły być wzorami dla siebie nawzajem: ze swojego wpływu na inne piszące damy słynęła Franciszka Urszula Radziwiłłowa, która znała się między innymi z Barbarą Radziwiłłową i z Antoniną Niemiryczową; Beata Maria Wołk-Łaniewska i Barbara Radziwiłłowa były siostrami i pewnie oddziaływały na siebie nawzajem; ta ostatnia mogła też stanowić wzorzec dla swojej wnuczki, Barbary Sołłohobówny (tłumaczki czasów stanisławowskich) - a i dla mężczyzn, na przykład jej syn Udalryk był poetą.

Jak widać, socjalizacja tłumaczek w Polsce w latach 1697-1763 przebiegała w podobny sposób, możemy więc założyć, że ich dyspozycje do tłumaczenia również były podobne: otrzymały najlepsze wykształcenie dostępne wówczas dla kobiet; chociaż nie miały przygotowania zawodowego, ich majątek i środowisko pozwalały im zdobyć umiejętności potrzebne do

znana francuska tłumaczka tamtego okresu, Anne Dacier, była córką profesora uniwersytetu (Garnier 2002: 16); osiemnastowieczne tłumaczki niemieckie omawiane przez Wolf (2005) przekładały dla zarobku, zazwyczaj razem z mężami.

${ }^{6}$ Pieretti pokazuje, że ,pisarki odgrywały znaczącą rolę w przekazywaniu idei i (...) często uznawały to za możliwą strategię kształtowania kultur oświeceniowych" (2002: 474, przeł K.D.); Whitfield (2002) opisuje wpływ, jaki wywarła Émilie du Châtelet na pole naukowe swoich czasów; a Garnier (2002) omawia filologiczny projekt popularyzacji wprowadzony w życie przez Anne Dacier. 
przekładania (typowy kapitał kulturowy, w jaki wyposażano wtedy damy, to były właśnie podstawowe kompetencje tłumaczeniowe: języki, zamiłowanie do literatury i obcych kultur, zwłaszcza francuskiej); ich otoczenie pozwalało im zaistnieć w polu kulturowym, a czasami wręcz do tego zachęcało. Innymi słowy, ich habitus klasowy zapewniał im dyspozycje odpowiednie dla tłumacza amatora, chociaż z całą pewnością nie predysponował ich do uległości i nieśmiałości. W następnym punkcie zobaczymy, jak to wpłynęło na ich decyzje tłumaczeniowe.

\section{Zachowania translatorskie}

Skupię się teraz na zachowaniach tłumaczeniowych tych kobiet: doborze tekstów źródłowych, języków i autorów, podejściu do tłumaczenia, decyzjach o publikowaniu lub pozostawieniu przekładów w rękopisach, motywacjach do podjęcia tłumaczenia i czytelnikach, do których się zwracały. Spróbuję też ustalić, czy ich pozycja społeczna, status wielkich dam, liczne inne obszary działalności poza przekładem oraz obszerny kapitał, którym dysponowały, miały wpływ na te ich wybory.

\subsection{Dobór tekstów źródłowych i tematów}

W korpusie znajduje się dziesięć pozycji, z których jedna (anonimowe Rady dane przyjaciółce) być może została mylnie przypisania Antoninie Niemiryczowej. Omawiane tłumaczki nie działały regularnie ani w uporządkowany sposób: najczęściej przekładały po jednym dziele, trudno więc w doborze tekstów źródłowych dopatrywać się jakichś prawidłowości (może oprócz Franciszki Urszuli Radziwiłłowej i Elżbiety Wielhorskiej). Niektóre z tych przekładów - świeckie - bywały już przedmiotem analiz, inne - zwłaszcza religijne - nie były jeszcze omawiane w literaturze. Zaczniemy od tych pierwszych.

Tłumaczenie Barbary Radziwiłłowej zostało napisane prozą i pozostawione w rękopisie. Jadwiga Miszalska (2005) oceniła przekład jako bardzo wierny: mało w nim dodatków tłumaczki, a i opuszczenia dotyczą zazwyczaj bardzo niewielkich partii. Czasami widać tendencję do porządkowania tekstu. Polszczyzna Radziwiłłowej jest czysta, słownictwo bogate i zdradzające obeznanie tłumaczki z dziedzinami takimi jak żeglarstwo, architektura czy 
wojna, ale przesadna nieraz wierność wobec oryginału powoduje, że tekst jest często niezgrabny składniowo i płaski stylistycznie, a w dalszych partiach także widocznie niedopracowany.

Fragment V księgi Artamène ou le Grand Cyrus Madeleine de Scudéry w thumaczeniu Marii Beaty Zawiszanki jest poprzedzony wstępem, w którym anonimowy wydawca opisuje, że oddał pismo do druku wbrew woli tłumaczki. Wybór wątku sentymentalnego - i pominięcie perypetii wojennych i politycznych - był w 1719 roku nowatorski i - jak wynika ze wstępu świadomy. Jak podsumowuje Hanna Dziechcińska, „Maria Beata, jako jedna z pierwszych, wprowadziła do literatury polskiej - za sprawą adaptowania do powieści sentymentalnej - temat miłości” (Dziechcińska 2005: 283).

Antonina Niemiryczowa przetłumaczyła wierszem francuską opowieść prozatorską Jeana de Préchaca, bardzo wówczas popularną, pod tytułem Le beau Polonais, wydaną jako Feniks rzadki na świecie. Zdaniem Gomulickiego:

Szkoda było pracy i uzdolnień Niemiryczowej do wyszywania poetyckiego haftu na kanwie tak mizernej! Poetka dała się porwać panującym prądom i wraz z innymi złożyła ofiarę na ołtarzu tak zwanego „ducha epoki” (Gomulicki 1912: 383).

Niektóre źródła (np. Sowiński 1821), wskazują także, że przetłumaczyła $\mathrm{z}$ francuskiego Rady dane przyjaciółce przez P.P., jednak inni autorzy (np. Gomulicki 1912), podają to w wątpliwość.

Franciszka Urszula Radziwiłłowa przetłumaczyła trzy sztuki Moliera: farsę Przeźrzane nie mija (Les amants magnifiques), Gwattem medyk (Le médecin malgré lui) oraz Komedię wytwornych i śmiesznych dzieweczek (Les précieuses ridicules). Badacze skarżą się na rażące galicyzmy i niezgrabne kalki z francuskiego, ale chwalą ją za łatwość operowania mową wiązaną (prozą napisana była tylko farsa Przeźrzane nie mija, najsłabsza) i żywy styl (Sowiński 1821). W analizie jej dramatów Maciejewska (2013) zwraca także uwagę, że nawet w thumaczeniach, skądinąd wiernych jak na tamte czasy, Radziwiłłowa wydobywała te wątki, które w całej jej twórczości interesowały ją najbardziej - miłość i erotykę.

W Archiwum Publicznym Potockich znajdują się dwie komedie Moliera w thumaczeniu Marii Potockiej, wpisane w 1749 roku: Komedia z francuskiego na polski wyttumaczona o drożacych się $i$ wykwintnych białogłowach... (polska wersja Les précieuses ridicules) i Komedia druga Zdradziectwa Skapina pokazujaca, z francuskiego na polski język wyttumaczona... (Les 
fourberies de Scapin). Są one jak na owe czasy bardzo nietypowe: przetłumaczone prozą, prawie nieudomowione, bardzo wierne. Niestety Komedia druga jest niekompletna, jej końcówka zaginęła (Rudnicka 1996).

Kazimierz Chłędowski pisze, że tłumaczenia z francuskiego Elżbiety Wielhorskiej ,cieszyły się zasłużonym rozgłosem, pani kuchmistrzowa przekładała dobrze", a jej utwory były chętnie grane przez teatry amatorskie, na przykład farsa Brueysa w jej przekładzie była podobno wystawiana na scenie dukielskiej (Chłędowski 1935: 260).

Chociaż różnorodność założeń i metod badawczych w przywoływanych analizach nie pozwala czynić prostych uogólnień ani bezpośrednich porównań, w oczy rzucają się powracające w wielu opracowaniach cechy wspólne: tłumaczki skupiały się na wątkach miłosnych, które były nowością w docelowym polu kulturowym, zaskakująco często przekładały wiernie jak na zwyczaje epoki i tłumaczyły z francuskiego na polski (oprócz Barbary Radziwiłłowej, która przekładała jednocześnie z włoskiego oryginału i jego francuskiego tłumaczenia). Te języki źródłowe są podobne jak w przypadku tłumaczek zachodnioeuropejskich: prestiżowe i używane w nowoczesnym dobrym towarzystwie. Jednak przyczyną ich wyboru może być to, że kobiet nie uczono języków klasycznych (Simon 1996: 52-53). Omówione pozycje to tłumaczenia modnych powieści świeckich, na przykład bardzo płodnego autora histoires galantes Jeana de Préchaca i czołowej przedstawicielki préciosité, Madeleine de Scudéry. Do tego świeckiego nurtu zalicza się też przekład Dianei siedemnastowiecznego pisarza włoskiego Francesca Loredana. Taki dobór tekstów był bezpośrednio związany ze społeczną pozycją tłumaczek jako pań swoich dworów i członkiń towarzystwa, aktywnych w modnych salonach.

Osobnym nurtem jest przekład utworów dla teatru - stosunkowo najczęstsze wśród nich są tłumaczenia Moliera, ale też innych modnych autorów tamtego czasu, nie zawsze nazwanych i nie zawsze wybitnych. Te teksty były wybierane przez Franciszkę Urszulę Radziwiłłową i Marię Potocką, które interesowały się teatrem (Potocka jako zagorzała czytelniczka i widz teatralny, Radziwiłłowa jako założycielka teatru dworskiego w Nieświeżu oraz autorka czy też tłumaczka i kompilatorka sztuk w nim odgrywanych). Elżbieta Wielhorska jako tłumaczka tekstów teatralnych jest opisywana we wspomnieniach - jej niepublikowane thumaczenia były wystawiane przez teatry amatorskie (Chłędowski 1935).

Damy te wybierały też rozważania religijne autorstwa francuskich jezuitów XVII i XVIII wieku (Michela Boutaulda, Jeana Crasseta czy Thomasa 
Sailly’ego), bardzo płodnych, a w XVIII wieku też chętnie tłumaczonych na polski.

Czasy saskie to okres kultury rękopiśmiennej, zarówno w Polsce, jak i na Zachodzie. W Europie Zachodniej było to spowodowane tym, że publikowanie uznawano za nieskromne i/lub wulgarne (Brown 2005: 112-113); w Polsce przyczyną była cenzura kościelna i fakt, że większość drukarń należała do zakonów (Klimowicz 2002: 16; Hernas 2002: 424; Migoń 1967: 53). Omawiane tłumaczki podpisywały jednak swoje tłumaczenia i wydawały je $\mathrm{e}^{7}$ pomimo tej globalnej tendencji - co także wskazuje na ich dążenie do widzialności, podobnie jak ich biografie i aktywne zaangażowanie w innych dziedzinach. Niewydane przekłady także były zresztą rozpowszechniane i znane (jak np. odgrywane w teatrach amatorskich sztuki Wielhorskiej czy Franciszki Urszuli Radziwiłłowej).

\subsection{Motywacje i odbiorcy}

Jeśli chodzi o motywy podjęcia pracy tłumaczeniowej, to wiemy, że nigdy nie były finansowe, ponieważ omawiane damy dysponowały pokaźnym kapitałem ekonomicznym, żadna z nich nie przekładała też na zamówienie. Jest to cecha, która odróżnia je od tłumaczek zachodnich tamtego okresu, dla których była to już praca zarobkowa (por. np. Agorni 2005: 820; Wolf 2005: 17-18). Można podejrzewać, że tłumaczyły dzieła religijne, żeby dać wyraz religijności publicznie lub chociażby przed swoimi spowiednikami, którzy często bywali jezuitami (por. Mariani 2015) (a dzieła takie były w końcu wydawane przez drukarnie zakonne). Pobudka mogła być też duchowa albo wynikać z wpływu otoczenia (jak u Lanckorońskiej, którą po śmierci matki wychowywali bardzo wierzący ojciec i jego bracia biskupi, albo u Franciszki Urszuli Radziwiłłowej). Motywacją w przypadku histoires galantes była natomiast moda - Gomulicki wszak wspomina, że na przykład wybór Le beau Polonais przez Niemiryczową nie mógł być spowodowany jakością oryginału i był niewart jej talentu, ale dzieło to było wówczas bardzo poczytne. Ciekawym przyczynkiem do zagadnienia motywacji może być fragment wstępu Niemiryczowej do Feniksa:

${ }^{7}$ Należy jednak pamiętać, że te pozostające w rękopisach trudniej znaleźć i mogły po prostu zostać przeoczone przez bibliografów. 
Wiem, że ją [książkę] każdy zna i czytał o polskim Kawalerze Walewskim z Beraldą w intrygach statecznej miłości zostającym, z francuskiego przetłumaczoną. Jednakże ja pracy mojej dokładam i tę historię wierszem opisuję r. p. 1750 dlatego, że już poniekąd zapomniana, żeby tedy nie poszła w zaniechanie starożytności (Niemiryczowa, cyt. za: Bibliografią Staropolską Estreichera).

Dodajmy, że tłumaczenie Niemiryczowej nie było jedynym spolszczeniem tej książki. Podobnie było z innymi pozycjami modnymi w owym czasie - nikomu nie przeszkadzało, że ta sama książka była tłumaczona już wcześniej ani że była już od dawna znana w docelowym polu kulturowym w innej wersji językowej. Co więcej, Czesław Hernas pisze: „Dwory magnackie XVII wieku, zazwyczaj wielostronnie powiązane z zagranicą, były ośrodkami podatnymi na wpływy szeroko pojętej mody europejskiej: w budownictwie i ubiorze, w zwyczajach i języku, w zainteresowaniach i gustach estetycznych" (Hernas 2002: 14). Potrzeba wzbogacenia docelowego pola kulturowego również nie była więc częstym motywem, ale w przypadku dzieł świeckich mogły czasami decydować kwestie ideologiczne (np. moralizatorskie) albo artystyczne - dwie z omawianych thumaczek, Franciszka Urszula Radziwiłłowa i Antonina Niemiryczowa, były wszak także autorkami tekstów oryginalnych.

Radziwiłłowa tworzyła poezje miłosne, traktaty o małżeństwie, a także utwory dla swojego teatru, oparte na starszych, bardzo różnorakich wzorcach. Jej twórczość translatorska jest przedłużeniem i dopełnieniem, nie zawsze odrębnym, twórczość oryginalnej. Podkreśla to jeszcze fakt, że jej cała twórczość została wydana w jednym tomie, bez specjalnej troski o ten podział ${ }^{8}$. Niemiryczowa $z$ kolei pisała własne poezje metafizyczne w duchu barokowo-rokokowym. Źródła dość zgodnie podkreślają, że mimo braku olśniewającego talentu wyróżnia się na tle innych twórców epoki czystością polszczyzny. Z jednej strony nie ma więc chyba w jej przypadku aż takiej jedności między dziełem oryginalnym i spolszczonym, chociaż z drugiej strony wybór formy wierszowanej do przekładu prozatorskiego tekstu źródłowego może być właśnie podyktowany tym, że była nade wszystko poetką.

Tłumaczki te przekładały jednak przede wszystkim dla rozrywki bądź dlatego, że było to zajęcie modne i prestiżowe, podejmowane dla pomnożenia kapitału symbolicznego. Nowicka-Jeżowa pisze o tym: „w buduarach

${ }^{8}$ Jest to oczywiście typowe dla wieku tłumaczek-pisarek tego okresu (por. Pieretti 2002: 479-483). 
osiemnastowiecznych dam polskich przekład stawał się bardziej formą zabawy towarzyskiej niż pracy literackiej" (2005: 14). Był to więc sposób na niepróżnujące próżnowanie (najbardziej chyba widoczne w przypadku nieopublikowanych w ogóle tłumaczeń) albo wyraz potrzeby duchowej: religijnej bądź emocjonalnej - może stąd wspomniane wyżej wejście tematu miłości do polskiego pola kulturowego między innymi dzięki Zawiszance czy Franciszce Urszuli Radziwiłłowej.

Ciekawą kwestią jest też projektowany przez tłumaczki czytelnik ich dzieł. Z jednej strony tłumaczyły raczej dla odbiorcy ze swojej sfery; z drugiej - jak już wspomniano, thumaczenie z francuskiego dla polskiej arystokracji w XVIII wieku nie było konieczne, bo był to język znany i używany w tych kręgach powszechnie. Być może więc adresatami było kółko najbliższych przyjaciół z beau monde, a bycie tłumaczką uważano za oznakę statusu intelektualnego wielkich pań9.

Pomimo bardzo słabego ogólnego poziomu intelektualnego tego okresu (a może właśnie dzięki niemu), jest to czas, kiedy kobiety po raz pierwszy ośmieliły się wkroczyć na krajowe pole literackie. Co więcej, tłumaczki czasów saskich były wszechstronnie uzdolnione, aktywne na wielu polach i kreatywne, a także dysponowały wszystkimi typami kapitałów, chociaż ich przekłady cierpią na te same wady co twórczość oryginalna tego czasu.

Tłumaczki te były arystokratkami przekładającymi dla przyjemności, a ich uprzywilejowana sytuacja miała wyraźny wpływ na ich zachowania translatorskie - dobór tekstów, czytelników i pobudki podjęcia tłumaczenia. Nie były one niewidoczne i nie podporządkowywały się powszechnie przyjętym w swojej epoce normom tłumaczeniowym - wręcz przeciwnie, były wystarczająco pewne siebie, żeby szukać swojego miejsca w docelowym polu kulturowym i wywierać wpływ zarówno na nie, jak i na inne pola; wprowadzać innowacje w kwestii doboru źródeł i tematów; a także publikować pod własnym nazwiskiem w czasach, kiedy nie było to rozwiązanie oczywiste nawet dla mężczyzn i dla autorów oryginalnych; były też uważane za tłumaczki bardzo wierne, czasami wręcz do tego stopnia, że gwałciły normy

9 Inaczej niż w przypadku tłumaczek zachodnich (por. Pieretti 2002; Wolf 2005; Garnier 2002; Whitfield 2002), nic nie wskazuje na to, żeby kierowały się chęcią wzbogacenia kultury docelowej, edukowania swoich czytelników czy też promowania swoich własnych poglądów na istotę tłumaczenia. Dla tłumaczek saskich przekład nie był jeszcze pierwszym krokiem na drodze do czegoś więcej, inaczej niż dla francuskich tłumaczek oświeceniowych (Pieretti 2002: 474). Takie motywy pojawią się w Polsce dopiero wśród tłumaczek stanisławowskich. 
docelowe. Żeby stać się pierwszymi kobietami w Polsce, które ośmieliły się wejść w pole literackie, musiały mieć nie tylko odwagę, ale przede wszystkim pewność siebie, którą zapewniał im ich status społeczny ${ }^{10}$.

Ta dość konsekwentna i szczególna praktyka tłumaczek saskich wynikała z ich uprzywilejowanej sytuacji i wysokiej pozycji, którą zajmowały. Wydaje się więc, że w pewnych epokach i w niektórych okolicznościach to nie niewidoczność i marginalność są cechami, które pozwalałyby tłumaczom i tłumaczkom zajmować pozycje w polu.

\section{Bibliografia}

Agorni M. 2005. A Marginal(ised) Perspective on Translation History: Women and Translation in the $18^{\text {th }}$ Century, ,Meta: Journal des Traducteurs/Meta: Translators' Journal" 50 (3), s. 817-830.

Bartoszewicz J. 1862. Krzysztof Zawisza wojewoda miński, w: K. Zawisza, Pamiętniki, Warszawa: Jan Zawisza, s. i-lxxiii.

Bibliografia Staropolska Estreichera, http://www.estreicher.uj.edu.pl/staropolska (dostęp: 22.11.2017).

Bogucka M. 2004. Women in Early Modern Polish Society: Against the European Background, Aldershot: Ashgate.

2008. Woman in the History of Europe, Warszawa: b.n.w.

Bourdieu P. 1998. Les règles de l'art. Genèse et structure du champ littéraire, Paris: Seuil. Brown S.A. 2005. Women Translators, w: S. Gillespie, D. Hopkins (red.), History of Literary Translation into English (1660-1790), Oxford: Oxford University Press, s. 111-120.

Chłędowski K. 1935. JM. Państwo Kuropatniccy, w: K. Chłędowski, Z przeszłości naszej i obcej, Lwów: Ossolineum, s. 244-268.

Delisle J., Woodsworth J. (red.). 2012. Translators Through History, Amsterdam: John Benjamins.

Dębska K. 2016. Foremothers. First Women Translators in Poland, „Studia Filologiczne Uniwersytetu Jana Kochanowskiego" 29 (2), s. 163-172.

${ }^{10}$ Ciekawie byłoby porównać status tłumaczek z sytuacją tłumaczy w tej samej epoce, jednak jedyna istniejąca historia tłumaczenia w Polsce (Sadkowski 2013), chociaż skupia się niemal wyłącznie na mężczyznach, omawia ich przekłady, a nie postaci autorów, a zbieranie potrzebnych danych z innych źródeł wykracza poza przedmiot niniejszego artykułu. Z pobieżnych uwag Sadkowskiego można wywnioskować, że miejsce tłumaczy w ówczesnym polu literackim było pewniejsze, a oni sami rzadziej niż jeszcze sto lat wcześniej bywali arystokratami (Sadkowski 2013: 32-51). Jednak może być to wynikiem selekcji dokonanej przez autora, który nie wyjaśnia swojej metody. 
Dziechcińska H. 2005. Maria Beata Zawiszanka - tlumaczka francuskiego romansu, w: A. Nowicka-Jeżowa, M. Prejs (red.), Barok polski wobec Europy. Sztuka przekładu, Warszawa: Anta, s. 277-283.

Dziubecki T. 2013. Rezydencja w Radzyniu Podlaskim jako miejsce ksztattujace wyobraźnię architektoniczna Stanisława Kostki Potockiego. Przyczynek do źródet architektury klasycyzmu w Polsce, „Architecturae et Artibus” 1, http://www.wa.pb. edu.pl/uploads/downloads/Artykul-3--1---2013.pdf (dostęp: 22.11.2017).

Garnier B. (2002) Anne Dacier, un esprit moderne au pays des Anciens. w: J. Delisle (red.), Portraits de traductrices, Ottawa: Presses universitaires d'Ottawa, s. 13-54. Gomulicki W. 1912. Zapomniana poetka polska, w: W. Gomulicki, Kłosy polskiej niwy, Warszawa: Orgelbrand, s. 289-382.

Gouanvic J.-M. 1995. Pour une sociologie de la traduction: le cas de la littérature américaine traduite en France après la Seconde Guerre mondiale (1945-1960), w: M. Snell-Hornby., Z. Jettmarova, K. Kaindl (red.), Translation as Intercultural Communication, Amsterdam: John Benjamins, s. 33-44.

1999. Sociologie de la traduction. La science-fiction américaine dans l'espace culturel français des années 1950, Arras: Artois Presses Université.

2007. Objectivation, reflexivité et traduction pour une re-lecture bourdieusienne de la traduction, w : M. Wolf, A. Fukari (red.), Constructing a Sociology of Translation, Amsterdam: John Benjamins, s. 79-92.

Hernas C. 2002. Barok, Warszawa: PWN.

Inghilleri M. 2005. The Sociology of Bourdieu and the Construction of the "Object” in Translation and Interpreting Studies, „The Translator” 11 (2), s. 125-145.

Jaszowski S. 1820. Krótka wiadomość o życiu i pismach Antoniny Niemierzycowej urodzonej z Jełowieckich, „Pszczoła Polska” 2 (8), s. 316-323.

Judkowiak B. 2008. Inny głos. Wokół ekspresji kobiecości w utworach Franciszki Urszuli Radziwitłowej, w: I. Maciejewska, K. Stasiewicz (red.), Kobieta epok dawnych w literaturze, kulturze i spoleczeństwie, Olsztyn: Littera, s. 224-236.

—_ 2013. Franciszka Urszula Radziwiłłowa - w poszukiwaniu własnego głosu, Poznań: Wydawnictwo Naukowe UAM.

Kaczyńska E. 2014. Barokowy uniwersalizm? (taciński utwór Gwilhelma Stanihursta w polskim przekładzie Krzysztofa Zawiszy), „Rocznik Przekładoznawczy” 9, s. $129-143$.

Klimowicz M. 2002. Oświecenie, Warszawa: PWN.

Kowalik J. 2001. Maria z Kątskich Potocka (ok. 1720-1768). Przyczynek do życia kulturalnego w Radzyniu w II połowie XVIII wieku, „Radzyński Rocznik Humanistyczny", t. I.

Łossowska I. 2002. Polskie przekłady powieściowe w XVIII wieku (wstępne rozpoznanie), w: I. Łossowska, Tradycja i nowoczesność dydaktycznej powieści Oświecenia w Polsce, Warszawa: Wydział Polonistyki UW, s. 15-26.

Łukaszewicz J. 2010. Marianna Maliszewska and her translation of Congrès de Cythère after Francesco Algarotti, „Przekładaniec” 24, s. 31-47.

Maciejewska I. 2008. Kobiecym piórem o milości, malżeństwie i erotyce (Regina Salomea z Rusieckich Pilsztynowa, Elżbieta Drużbacka, Franciszka Urszula Radziwitłowa), 
w: I Maciejewska, K. Stasiewicz (red.) Kobieta epok dawnych w literaturze, kulturze i społeczeństwie, Olsztyn: Littera, s. 213-224.

2013. Miłość i erotyzm w piśmiennictwie czasów saskich, Olsztyn: Wydawnictwo Uniwersytetu Warmińsko-Mazurskiego.

Mariani A. 2015. Aktywność jezuickich kapelanów nadwornych prowincji litewskiej. Między ustawodawstwem zakonnym a praktyka, ,,Rocznik Lituanistyczny” 1, s. 37-82. Meylaerts R. 2010. Habitus and Self-Image of Native Literary Translators in Diaglossic Societies, „Translation and Interpreting Studies” 5 (1), s. 1-19.

Migoń K. 1967, Piśmiennictwo obce w polskiej produkcji wydawniczej czasów saskich, „Acta Universitatis Vratislaviensis. Bibliotekoznawstwo" V, s. 31-58.

Miszalska J. 2003. ,Kolloander wierny” ' ,,Piękna Dianea”: polskie przekłady włoskich romansów barokowych $w$ XVII wieku $i$ w epoce saskiej na tle ówczesnych teorii romansu i przekładu, Kraków: Universitas.

2005. Polskie przektady utworów Giovan Francesca Loredana, w: A. Nowicka-Jeżowa, M. Prejs (red.), Barok polski wobec Europy. Sztuka przekładu, Warszawa: Wydawnictwo Anta, s. 179-192.

Nowicka-Jeżowa A. 2005. Myśli wstępne o przekładzie w literaturze i kulturze baroku, w: A. Nowicka-Jeżowa, M. Prejs (red.), Barok polski wobec Europy. Sztuka przekładu, Warszawa: Wydawnictwo Anta.

Oworuszko E. 2014. Pozostałości ksiegozbioru Potockich z Radzynia w zbiorach Biblioteki Narodowej w Warszawie, „Radzyński Rocznik Humanistyczny” 12, s. 61-95, http://www.rasil.home.pl/rrh/rrh_12/04_oworuszko.pdf (dostęp: 14.12.2018).

Pieretti M.-P. 2002. Women Writers and Translation in Eighteenth-Century France, „The French Review" 75 (3), s. 474-488.

Pietrow-Ennker B. 1992. Women in Polish Society: A Historical Introduction, w: R. Jaworski, B. Pietrow-Ennker (red.), Women in Polish Society, New York: Boulder, s. 1-30. Rabowicz E. 1978. Niemiryczowa Antonina (ok. 1700-1780), „PSB” 23, s. 1-3.

Roćko A. 1998. Wizerunek artystyczny Antoniny Niemiryczowej, w: K. Stasiewicz (red.), Pisarki polskie epok dawnych, Olsztyn: Wyższa Szkoła Pedagogiczna, s. 129-141. Roman S. 1962. Le statut de la femme dans l'Europe orientale (Pologne et Russie) au Moyen Age et aux temps modernes, w: J. Poirier (red.), La femme, pt. 2, Bruxelles: Editions de la Librairie encyclopédique, s. 389-403.

Rudnicka J. 1996. Maria z Katskich Potocka jako thumaczka Moliera, w: K. Stasiewicz, S. Achremczyk, (red.), Między barokiem a oświeceniem. Nowe spojrzenie na czasy saskie, Olsztyn: OBN, s. 285-296.

Sadkowski W. 2013. Odpowiednie dać stowu stowo, Toruń: Adam Marszałek.

Scudéry M. de. 1719. Aryamen. Romans, to jest Historia zmyślona o Aryamenie, Warszawa: S.J.

Sela-Sheffy R. 2005. How to Be a (Recognized) Translator. Rethinking Habitus, Norms, and the Field of Translation, „Target” 17 (1), s. 1-26.

Simeoni D. 1998. The Pivotal Status of the Translator's Habitus, „Target” 10 (1), s. 1-39.

Simon S. 1996. Gender in Translation, London, New York: Routledge.

Sowiński J. 1821. O uczonych Polkach, Krzemieniec: Glücksberg.

Szklarska E. 1987. Radziwitt Mikołaj Faustyn (1688-1746), „PSB” 30, s. 361-363. 
Vorderobermeier G.M. (red.), 2014. Remapping Habitus in Translation Studies, Amsterdam-New York: Rodopi.

Whitfield A. 2002. Émilie du Châtelet, traductrice de Newton, ou la ,traduction-confirmation", w: J. Delisle (red.), Portraits de traductrices, Ottawa: Presses universitaires d'Ottawa, s. 87-116.

Widacka H. 2016. Teatr księżnej Radziwiłlowej, Pałac w Wilanowie, http://www.wilanow-palac.pl/teatr_ksieznej_radziwillowej.htm (dostęp: 14.09.2016).

Wielka genealogia Minakowskiego, http://www.sejm-wielki.pl (dostęp: 10.02.2017).

Wierzbicka-Michalska K. 1977. Moszyński August Fryderyk h. Nałęcz (1731-1786), „PSB” 22, s. 108-112.

1987. Radziwillowa Franciszka Urszula (1705-1753), „PSB” 30, s. 388-390.

Wolf M. 2005. The Creation of a „Room of One's Own”. Feminist Translators as Mediators between Cultures and Genders, w: J. Santaemilia (red.), Gender, Sex and Translation, Manchester: St Jerome, s. 15-23.

— 2007. Introduction, w: M. Wolf, A. Fukari (red.), Constructing a Sociology of Translation, Amsterdam: John Benjamins, s. 1-36.

Xu M., Chu C.Y. 2015. Translators' Professional Habitus and the Adjacent Discipline. The Case of Edgar Snow, „Target” 27 (2), s. 173-191.

Zawiszewska A. 2010. ,,Ttumaczka Morgana i Taylora”. O Aleksandrze Bąkowskiej i jej działalności społecznej, „Przekładaniec” 24 (2), 50-89.

\section{Załącznik}

O niektórych polskich tłumaczkach osiemnastowiecznych brak jakichkolwiek informacji. Imiona innych są tylko znane z biografii mężczyzn, z którymi były związane. Notki o niektórych z nich zamieszczam poniżej, żeby zachować chociaż te szczątkowe fakty.

Elżbieta z Potockich Szczuka (ok. 1694-?): Estreicher (Bibliografia Staropolska Estreichera) zaznacza tylko, że była siostrą „Antoniego wojewody". Zgodnie z danymi z Wielkiej genealogii Minakowskiego pasuje to do Antoniego Michała Potockiego (zm. 1766), wojewody bełskiego w latach 1732-1763, podstolego wielkiego litewskiego. Jej matką była Teresa Tarło, kasztelanówna zawichojska, ojcem Aleksander Jan Potocki, podkomorzy halicki, wojewoda smoleński. Elżbieta miała dwóch braci i siostrę. Jej mężem był Marcin Szczuka, starosta wąwolnicki (1698-1728). Ponieważ jej matka zawarła ślub z Aleksandrem w 1693 roku, można założyć, że Elżbieta urodziła się w latach 90. XVII wieku. 
Aleksandra z Załuskich Lanckorońska (ok. 1690-1744) była kasztelanową gostyńską. Według Minakowskiego urodziła się w latach 90. XVII wieku, jej matką była Teresa z Podkańskich, ojcem Aleksander Józef Załuski, wojewoda rawski. Aleksandra miała liczne rodzeństwo, które po wczesnej śmierci matki w 1702 roku wychowywali samotnie ojciec dewot i jego trzej bracia biskupi. W 1717 roku wyszła za mąż za Wojciecha Lanckorońskiego, kasztelana gostyńskiego, z którym miała trzy córki i syna.

Elżbieta z Ogińskich Wielhorska (1731-1771) według Minakowskiego była córką Anny Wiśniowieckiej i Józefa Ogińskiego, wojewody trockiego, a od 1754 roku żoną Michała Wielhorskiego, z którym miała trzech synów urodzonych w latach 50. XVIII wieku. Mąż był kuchmistrzem wielkim litewskim, oboźnym wielkim koronnym, posłem konfederacji barskiej we Francji, pisarzem politycznym (Chłędowski 1935).

Teofila z Potockich Moszyńska (ok. 1740-ok. 1800): Estreicher pisze tylko, że była krajczyną i żoną Augusta Moszyńskiego. Według Minakowskiego jej rodzicami byli Helena Zamoyska i Stanisław Potocki, wojewoda poznański, kijowski i smoleński. Miała kilkanaścioro rodzeństwa i przyrodniego rodzeństwa. Jako przybliżoną datę urodzenia podaje się 1740 rok, ale musiała urodzić się wcześniej, skoro jej tłumaczenie Boutaulda wyszło w 1754 roku, a w 1755 roku poślubiła Augusta Moszyńskiego, w 1761 roku urodziła jedynego syna Jana Nipomucena, a w 1764 roku przeprowadzono rozwód. Można mniemać, że jego przyczyną było prowadzenie się męża, który był kobieciarzem i roztrwonił majątek. Podobno dożyła końca XVIII wieku. Żadne inne informacje o jej życiu nie są dostępne (Wierzbicka-Michalska 1977). 